\title{
Berberine enhances inhibition of glioma tumor cell migration and invasiveness mediated by arsenic trioxide Tseng-Hsi Lin ${ }^{\dagger 1,3}$, Hsing-Chun Kuo ${ }^{\dagger 1,4}$, Fen-Pi Chou ${ }^{1}$ and Fung-Jou Lu*2
}

\author{
Address: ${ }^{1}$ Institute of Biochemistry and Biotechnology, Chung Shan Medical University, Taichung 402, Taiwan, ${ }^{2}$ School of Applied Chemistry, \\ Chung Shan Medical University, Taichung, Taiwan, ${ }^{3}$ Division of Hematology, Department of Internal Medicine, Taichung Veterans General \\ Hospital, Taichung, Taiwan and ${ }^{4}$ Department of Medical Research, Chang Gung Memorial Hospital, Kaohsiung Medical Center, Kaohsiung 833, \\ Taiwan \\ Email: Tseng-Hsi Lin - jth.lin@gmail.com; Hsing-Chun Kuo - guscsi@gmail.com; Fen-Pi Chou - fpchou@csmu.edu.tw; Fung- \\ Jou Lu* - fjlu@csmu.edu.tw \\ * Corresponding author †Equal contributors
}

Published: 25 February 2008

BMC Cancer 2008, 8:58 doi:10.1/86/147|-2407-8-58
Received: 3 March 2007

Accepted: 25 February 2008

This article is available from: http://www.biomedcentral.com/I47/-2407/8/58

(c) 2008 Lin et al; licensee BioMed Central Ltd.

This is an Open Access article distributed under the terms of the Creative Commons Attribution License (http://creativecommons.org/licenses/by/2.0), which permits unrestricted use, distribution, and reproduction in any medium, provided the original work is properly cited.

\begin{abstract}
Background: Arsenic trioxide $\left(\mathrm{As}_{2} \mathrm{O}_{3}\right)$ exhibits promising anticarcinogenic activity in acute promyelocytic leukemic patients and induces apoptosis in various tumor cells in vitro. Here, we investigated the effect of the natural alkaloid berberine on $\mathrm{As}_{2} \mathrm{O}_{3}$-mediated inhibition of cancer cell migration using rat and human glioma cell lines.

Methods: The 3-(4,5-dimethylthiazol-2-yl)-2,5-diphenyl tetrazolium bromide (MTT) assay was used to determine the viability of rat $\mathrm{C} 6$ and human $\mathrm{U}-87$ glioma cells after treatment with $\mathrm{As}_{2} \mathrm{O}_{3}$ or berberine, and after co-treatment with $\mathrm{As}_{2} \mathrm{O}_{3}$ and berberine. The wound scratch and Boyden chamber assays were applied to determine the effect of $\mathrm{As}_{2} \mathrm{O}_{3}$ and berberine on the migration capacity and invasiveness of glioma cancer cells. Zymography and Western blot analyses provided information on the effect of $\mathrm{As}_{2} \mathrm{O}_{3}$ and berberine on the intracellular translocation and activation of protein kinase $C$ (PKC), and some PKCrelated downstream factors. Most assays were performed three times, independently, and data were analyzed using ANOVA.

Results: The cell viability studies demonstrated that berberine enhances $\mathrm{As}_{2} \mathrm{O}_{3}$-mediated inhibition of glioma cell growth after $24 \mathrm{~h}$ incubation. Untreated control cells formed a confluent layer, the formation of which was inhibited upon incubation with $5 \mu \mathrm{M} \mathrm{As}_{2} \mathrm{O}_{3}$. The latter effect was even more pronounced in the presence of $10 \mu \mathrm{M}$ berberine. The $\mathrm{As}_{2} \mathrm{O}_{3}$-mediated reduction in motility and invasion of glioma cells was enhanced upon co-treatment with berberine. Furthermore, it has been reported that PKC isoforms influence the morphology of the actin cytoskeleton, as well as the activation of metalloproteases MTIMMP and MMP-2, reported to be involved in cancer cell migration. Treatment of glioma cells with $\mathrm{As}_{2} \mathrm{O}_{3}$ and berberine significantly decreased the activation of PKC $\alpha$ and $\varepsilon$ and led to actin cytoskeleton rearrangements. The levels of two downstream transcription factors, myc and jun, and MTI-MMP and MMP-2 were also significantly reduced.

Conclusion: Upon co-treatment of glioma cells with $\mathrm{As}_{2} \mathrm{O}_{3}$ and berberine, cancer cell metastasis can be significantly inhibited, most likely by blocking the PKC-mediated signaling pathway involved in cancer cell migration. This study is potentially interesting for the development of novel chemotherapeutic approaches in the treatment of malignant gliomas and cancer development in general.
\end{abstract}




\section{Background}

Arsenic trioxide $\left(\mathrm{As}_{2} \mathrm{O}_{3}\right)$ can effectively induce apoptosis in acute promyelocytic leukemia (APL) cells in vitro and in vivo [1-4] and was approved by the United States Food and Drug Administration in 2000 for the treatment of patients with relapsed/refractory APL. Although $\mathrm{As}_{2} \mathrm{O}_{3}$ has been evaluated in clinical studies for the treatment of acute myelogenous leukemia, myelodysplastic syndrome, and multiple myeloma [5], the diverse sensitivities of different types of tumor cells to this drug limits its clinical application in a wider spectrum of hematological and, especially, solid malignancies [6-12]. The antiproliferation mechanisms of $\mathrm{As}_{2} \mathrm{O}_{3}$ in solid tumors are not well known, and studies on the anti-invasive effects are rare [13]. Most recently, $\mathrm{As}_{2} \mathrm{O}_{3}$ was reported to induce apoptosis in a human neuroblastoma cell line via the upregulation of caspase 3 [14]. Paradoxically, arsenic compounds are well-known human carcinogens that may cause, at relatively high concentrations and/or exposures times [15], tumors in a variety of human tissues including skin, liver, and kidneys [10].

The poor prognosis of human malignant gliomas is due to their invasion and recurrence. The invasion of glioma into normal brain tissue is a major challenge to clinical intervention because these tumors often highly infiltrate the surrounding brain tissues. An important characteristic of high-grade central nervous system tumors is the presence of massively upregulated protein kinase $C$ (PKC) when compared to normal glia $[16,17]$. PKC represents a family of lipid-dependent serine/threonine kinases that consist of at least 12 mammalian isoforms divided into three subfamilies including conventional or classic PKCs (cPKC), non-classic or novel PKCs (nPKC), and atypical PKCs [18]. The activation of most PKC isoforms depends on the translocation from the cytosol to subcellular compartments such as the cell membrane [19]. The enhanced PKC levels in glioma cells have been suggested to be critical to the hyper-proliferative state and the resistance to apoptosis as well as glioma invasion $[20,21]$. Indeed, treatment of the human glioblastoma cell line T98G with hypericin results in a significant inhibition of the cell invasion, an effect that is also obtained using specific PKC inhibitors [22], and a high level of PKC $\alpha$ expression in a human colon-adenocarcinoma cell line has been correlated with high migratory activity of colon carcinoma cells [23]. Consequently, specific PKC inhibition is thought to control tumor growth and development $[18,24]$. PKC $\alpha / \beta$ inhibitor Go6976 blocks the invasion of urinary bladder carcinoma cells [25] and PKC antisense oligonucleotide LY900003 is in clinical development as a drug against breast cancer to be used in concert with, for instance, chemotherapy [26].
Tumor invasion including that of high-grade malignant gliomas is, for a significant part, mediated by the overproduction of a number of tissue-digesting matrix metalloproteinases (MMPs) such as MMP-2 (type IV collagenase or gelatinase A) and their activators such as membranetype 1 metalloproteinase (MT1-MMP) [27,28]. Inhibition of MMP-2 in human glioma cell line U-87 results in a dramatic reduction in cell invasion [29], and induction of PKC activation in a D54 human glioblastoma cell line results in enhanced invasion through the activation of several metalloproteases including MMP-2 [30].

Berberine, a natural alkaloid, has been extensively studied and shown to exhibit multiple pharmacological activities such as anti-bacterial [31], anti-oxidative [32], and anticancer and anti-inflammation capabilities [32-34]. Berberine also sensitizes human glioma cells to ionizing radiation in vitro [35]. Recently, berberine has been shown to exert anti-metastatic properties in non-small lung cancer cells [36], to be cytotoxic to human tumor U937 and murine melanoma B16 cells [37], and to inhibit growth and induce G1 cell cycle arrest followed by apoptosis in human epidermoid carcinoma A431 cells [38].

Although treatment with $\mathrm{As}_{2} \mathrm{O}_{3}$ induces clinical remission in patients with APL without severe toxicity, relapse with $\mathrm{As}_{2} \mathrm{O}_{3}$-resistant cells still occurs [39] and, in addition, $\mathrm{As}_{2} \mathrm{O}_{3}$ remains a toxic compound at relatively high concentrations or exposures [15]. Thus, alternative strategies that would enhance cellular sensitivity to $\mathrm{As}_{2} \mathrm{O}_{3}$, thereby lowering its concentration of action, would be helpful. In the present study, we report for the first time that berberine enhances the antiproliferation activity of $\mathrm{As}_{2} \mathrm{O}_{3}$ in rat glioma and human malignant glioma cell lines. In addition, we investigated $\mathrm{As}_{2} \mathrm{O}_{3}$-mediated suppression of glioma cell invasion which likely involves PKC signaling, ERK phosphorylation, and MMP-2 activation. Thus, this study may have important clinical applications in the design of strategies to treat human glioma.

\section{Methods \\ Cell culture}

The rat $\mathrm{C} 6$ glioma cell line was originally derived from a $\mathrm{N}$-nitrosomethylurea-induced rat brain tumor [40]. C6 rat cancer cells and U-87 human malignant glioma cells were cultured in minimal essential medium and RPMI (Gibco, Carlsbad, California) supplemented with $10 \%$ fetal calf serum (Gibco) and antibiotics (100 units/ml penicillin and $100 \mu \mathrm{g} / \mathrm{ml}$ streptomycin) at $37^{\circ} \mathrm{C}$ in a humidified atmosphere composed of $5 \% \mathrm{CO}_{2}$ and $95 \%$ air. All experiments were performed in plastic tissue culture flasks, dishes, or in microplates (Nunc, Naperville, Denmark). 


\section{Chemical reagents and antibodies}

$\mathrm{As}_{2} \mathrm{O}_{3}$ was obtained from TTY Biopharm (Taipei, Taiwan). Berberine, gelatin, and 3-(4,5-dimethylthiazol-2-yl)-2,5diphenyl tetrazolium bromide (MTT) were purchased from Sigma-Aldrich (St. Louis, Missouri). Anti-phosphop44/42 MAPK and horseradish peroxidase-linked antirabbit or mouse IgG were from Cell Signaling Technology (Beverly, Massachusetts). Anti-MT1-MMP1, MMP-2, and PKCs $\alpha$ and $\varepsilon$ were purchased from Santa Cruz Biotechnology (Santa Cruz, California). Monoclonal anti-ornithine decarboxylase (ODC) antibody was purchased from Sigma-Aldrich.

\section{Cell growth and proliferation assay}

Cell viability was determined using the MTT quantitative colorimetric assay [41]. The cells were seeded at $5 \times 10^{4}$ cells $/ \mathrm{ml}$ density and incubated with berberine or $\mathrm{As}_{2} \mathrm{O}_{3}$ at various concentrations $(0,1,2,5,10$, and $20 \mu \mathrm{M})$ for 24 h. Thereafter, the medium was changed and cells were incubated with MTT $(0.5 \mathrm{mg} / \mathrm{ml})$ for $4 \mathrm{~h}$. The viable cell number is directly proportional to the production of formazan, which can be measured spectrophotometrically $(\lambda$ $=563 \mathrm{~nm}$ ) upon solubilization with isopropanol. Cell growth was determined by counting the number of cells at indicated periods of time using a Coulter counter and measured using the trypan blue $(0.2 \%)$ exclusion assay [42].

\section{Boyden chamber assay}

The Boyden chamber assay used for the analysis of tumor cell migration is based on a chamber with two mediumfilled compartments. C6 and U-87 glioma cells were allowed to grow as discrete colonies and treated with $\mathrm{As}_{2} \mathrm{O}_{3}$ or berberine as described above. Cells were collected by trypsinization and suspended in serum-free medium at $1 \times 10^{5} / \mathrm{ml}$. Migration assays were carried out in a 48-well chemotaxis chamber (Neuro-Probe, Gaithersburg, Maryland). The medium containing 10\% fetal calf serum was added to the lower chamber. The lower and upper chambers were separated by an $8 \mu \mathrm{m}$ pore size polycarbonate membrane (Poretics, Livermore, California). Cells were allowed to migrate for $24 \mathrm{~h}$ at $37^{\circ} \mathrm{C}$ in a humidified atmosphere containing $5 \% \mathrm{CO}_{2}$. The membrane was fixed in methanol for $10 \mathrm{~min}$ and stained with modified Giemsa stain (Sigma-Aldrich) for $1 \mathrm{~h}$. Cells on the upper side of the membrane were removed by cotton swabs. Cells on the lower side of the membrane were counted using a light microscope at $200 \times$ magnification. The number of cells that migrated to the lower side of the membrane was determined [36].

\section{Matrigel invasion assay}

Rat C6 and human U87 glioma cells were incubated with Dulbecco's modified Eagle's medium (DMEM) in 10\% fetal calf serum and then collected by trypsinization. Cells $\left(1 \times 10^{5} / \mathrm{ml}\right)$ in serum-free medium were added to an inner cup of the 48-well Transwell chamber (Corning Life Sciences, Corning, New York) that had been coated with $50 \mu \mathrm{l}$ of Matrigel (BD Biosciences, Franklin Lakes, New Jersey; 1:10 dilution in serum-free medium). Medium supplemented with $10 \%$ serum or indicated agent was added to the outer cup. After $24 \mathrm{~h}$, cells that had migrated through the Matrigel and the $8 \mu \mathrm{m}$ pore size membrane were fixed, stained, and counted under a light microscope. Each experiment was performed in triplicate.

\section{Scratch assays}

Scratch assays were performed by plating cells in 6-well culture dish. After C6 glioma cells were allowed to attach and reach confluence, a scratch $(4 \mathrm{~mm})$ was made through the culture dish. The cells were washed twice with phosphate-buffered saline ( $\mathrm{PBS}, \mathrm{pH}=7$ ) before their subsequent incubation with culture medium in the absence (control) or presence of $\mathrm{As}_{2} \mathrm{O}_{3}$ or combinations at appropriate concentrations. Photographs of treated cells moving within the scratch were taken at the indicated time points. Openlab v3.0.2 image analysis software (Improvision, Coventry, United Kingdom) was used to quantify the area progressively filled with cells over the period of the experiment.

\section{Preparation of total cell extracts and immunoblot analysis Cellular lysates were prepared by suspending $1 \times 10^{6}$ cells in $200 \mu$ l of lysis buffer ( $137 \mathrm{mM} \mathrm{NaCl}, 15 \mathrm{mM}$ EGTA, 0.1 $\mathrm{mM}$ sodium orthovanadate, $15 \mathrm{mM} \mathrm{MgCl} \mathrm{Mg}_{2}, 0.1 \%$ Triton $\mathrm{X}-100,25 \mathrm{mM}$ MOPS, $100 \mu \mathrm{M}$ phenylmethylsulfonyl flu- oride and $20 \mu \mathrm{M}$ leupeptin, adjusted to $\mathrm{pH}$ 7.2). The cells were disrupted by sonication and extracted at $4{ }^{\circ} \mathrm{C}$ for 30 min. The supernatant was quantitated using the Pierce BCA protein quantitation assay (Pierce, Rockford, Illi- nois) and were electrotransferred to Immobilon-P mem- branes (Millipore, Bedford, Massachusetts). Detection of specific proteins was carried out with an enhanced chem- oluminescence Western blot kit [43].}

\section{Immunofluorescent staining assay}

One day after plating on coverslips, the cells were treated with empty vehicle or indicated agent for appropriate times. Following the treatment period, the cells were fixed in $2 \%$ formaldehyde in PBS for $10 \mathrm{~min}$. The cells were then permeabelized in PBS containing 1\% bovine serum albumin and $0.1 \%$ Triton $\mathrm{X}-100$ for $10 \mathrm{~min}$. The cells were then incubated for $1 \mathrm{~h}$ with rabbit anti-F-actin (Abcam, Cambridge, Massachusetts), washed in PBS, and incubated for $1 \mathrm{~h}$ with anti-rabbit tetramethylrhodamine isothiocyanate (TRITC) labeled secondary antibodies (Molecular Probes, Carlsbad, California). Following three additional washes, the coverslips were mounted on glass slides in anti-fade medium. The images were then col- 
lected using fluorescence microscopy (Carl Zeiss, Oberkochen, Germany).

\section{PKC translocation assay}

Cells were washed twice with PBS and lysed by suspension in $0.5 \mathrm{ml}\left(2 \times 10^{6}\right.$ cells $)$ of ice-cold homogenization buffer (20 mM Tris - $\mathrm{HCl}$ [pH 7.5], 2 mM EDTA, 2 mM EGTA, 6 $\mathrm{mM} \mathrm{DTT}, 50 \mu \mathrm{g} / \mathrm{ml}$ aprotinin, $48 \mu \mathrm{g} / \mathrm{ml}$ leupeptin, 5 $\mu \mathrm{mol} / \mathrm{l}$ pepstatin A, $1 \mathrm{mM}$ phenylmethylsulfonyl fluoride). The homogenate was sonicated and then centrifuged for $10 \mathrm{~min}$ at $500 \times \mathrm{g}$. The supernatant was centrifuged at $100,000 \times g$ for $1 \mathrm{~h}$ at $4^{\circ} \mathrm{C}$. The resulting supernatant was designated as the soluble (cytosol) fraction. The pellet was solubilized in $200 \mu \mathrm{l}$ of homogenization buffer containing $1 \%$ Triton X-100 and centrifuged at $15,000 \times g$ for $15 \mathrm{~min}$ at $4{ }^{\circ} \mathrm{C}$. The supernatant was designated as the particulate (membrane) fraction. All extraction procedures were performed at $4{ }^{\circ} \mathrm{C}$. The protein concentration in cell fractions was determined using a commercial protein assay (Bio-Rad, Hercules, California) with bovine serum albumin (BSA) as a standard. Extractions for immunoblotting were based on previously described methods.

\section{Zymography}

MMP-2 and MMP-9 enzymatic activities were assayed by gelatin zymography with some modifications. Culture supernatants were diluted 4:1 with sample $4 \times$ buffer (17.4\% sodium dodecyl sulphate, $7 \%$ sucrose, and phenol red in Tris-HCl, $\mathrm{pH}$ 6.8). Sixteen microliters of sample was added to the wells under non-reducing and nondenaturing conditions. After electrophoresis, the gel was washed twice with washing buffer, followed by a brief rinsing in washing buffer with Triton X-100. The gel was then placed in PBS, pH 7.4 containing $0.9 \mathrm{mmol} \mathrm{CaCl}_{2}$ and $\mathrm{MgCl}_{2}$ and incubated overnight at room temperature on a moving platform. The next morning, the gel was stained with Coomassie Brilliant Blue G250 $(0.1 \%$ in $25 \%$ methanol and $10 \%$ acetic acid in water) and destained in the same solution in absence of the dye.

\section{Statistical analyses}

Data are described as the mean \pm standard deviation. For Figure 1, each treatment was compared to its relative control using a Student $t$ test. For Figures 2, 3, 4, and 5, treatment effects were compared using ANOVA with Bonferroni correction. The latter analysis does not apply to Figure 6, but was used to analyze the data presented in Figure 7 . The data were analyzed using the SAS statistical software package "SigmaPlot", version 9.0 (SAS Institute Inc., Cary, North Carolina). The significance level was established at $\mathrm{P}<0.05$. The quantitative data were presented as three repeats from one independent experiment. This is representative of two independent experiments with similar results.

\section{Results \\ $\mathrm{As}_{2} \mathrm{O}_{3}$ and berberine inhibit the proliferation of $\mathrm{C} 6$ and $\mathrm{U}$ - 87 glioma cells}

In the first instance, the effect of $\mathrm{As}_{2} \mathrm{O}_{3}$ and berberine, applied separately or in combination, on the viability of C6 rat glioma cells and U-87 human malignant glioma cells was investigated. The cell proliferation was determined using the MTT assay performed with logarithmically growing glioma cells treated with $\mathrm{As}_{2} \mathrm{O}_{3}$ and berberine (Figures $1 \mathrm{~A}$ and $1 \mathrm{~B}$ ). Within $24 \mathrm{~h}$ of the addition of $5 \mu \mathrm{M} \mathrm{As}_{2} \mathrm{O}_{3}$ and $10 \mu \mathrm{M}$ berberine alone on the C6 cells, proliferation was reduced to $78 \%$ and $88 \%$, respectively $(P<0.05)$. Treatment with the same concentrations of $\mathrm{As}_{2} \mathrm{O}_{3}$ or berberine did not elicit marked cytotoxic effects on U-87 cells (Figure 1B). However, at a concentration of $20 \mu \mathrm{M}$, decreased cell viability was observed. Interestingly, based on the trypan blue dye exclusion assay, it was observed that $5 \mu \mathrm{M} \mathrm{As}_{2} \mathrm{O}_{3}$ and $10 \mu \mathrm{M}$ berberine combined treatment exhibited a minor effect on the viability of $\mathrm{C} 6$ and U-87 cells (data not shown). A dose-dependent effect on the inhibition of the $\mathrm{C} 6$ or U-87 glioma cell proliferation at lower agent concentrations was observed (Figure 1C). Co-treatment with $5 \mu \mathrm{M} \mathrm{As}_{2} \mathrm{O}_{3}$ and $10 \mu \mathrm{M}$ berberine, concentrations used for all further analyses, led to an inhibition of the cell proliferation and indicated no major signs of apoptosis, suggesting that another biological or pharmacological function played a role.

\section{Berberine enhances $\mathrm{As}_{2} \mathrm{O}_{3}$-mediated reduction in glioma cell migration and invasion}

Using the scratch-wound assay, a continuous rapid movement was observed for all cells, but a resultant movement of a glioma cell migration front was clearly evident at 24 h, where a highly confluent $(90 \%-100 \%)$ monolayer region gradually migrated into the cell-free 'scratch' region (Figure 2A). In the presence of $5 \mu \mathrm{M} \mathrm{As}_{2} \mathrm{O}_{3}$, migration was significantly reduced after 12 and $24 \mathrm{~h}$ of incubation, whereas co-treatment with $5 \mu \mathrm{M} \mathrm{As}_{2} \mathrm{O}_{3}$ and $10 \mu \mathrm{M}$ berberine led to a virtually complete inhibition of cell migration (Figures 2A and 2B).

Cell proliferation and invasive behaviors are important characteristics of cancer cells and indicators of malignance, and both are targets of anti-cancer agent development [44]. The Boyden chamber assay was used to evaluate the inhibitory effect of combined treatment with $\mathrm{As}_{2} \mathrm{O}_{3}$ and berberine on $\mathrm{C} 6$ or U-87 glioma cell migration and invasiveness. The observations revealed that berberine- $\mathrm{As}_{2} \mathrm{O}_{3}$ co-treatment resulted in a remarkable inhibition of glioma cell migration as compared to either treatment alone (Figure 3), which supported the results obtained with the scratch-wound assay (Figure 2). In addition, co-treatment with $\mathrm{As}_{2} \mathrm{O}_{3}$ and berberine also exhibited a significant anti-invasive effect on glioma cells 

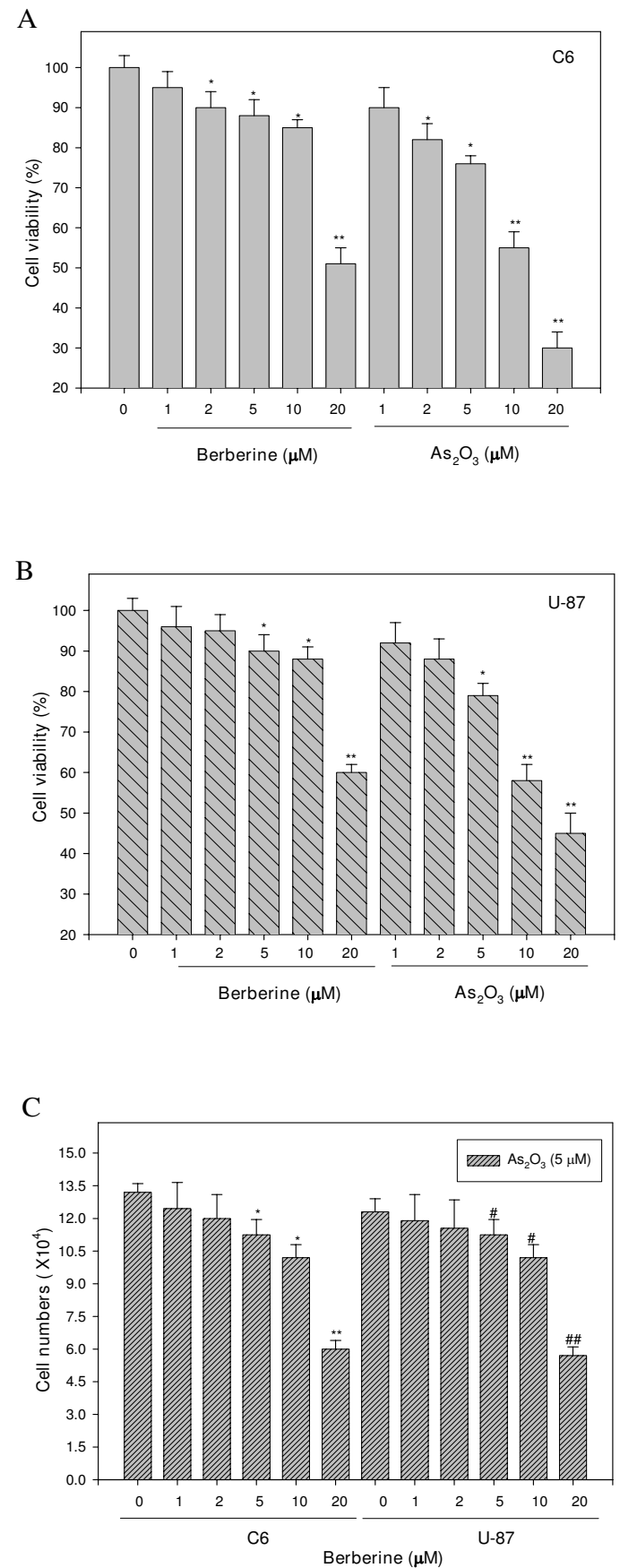

\section{Figure I}

Evaluation of the cell viability of $\mathrm{C} 6$ glioma and human $\mathrm{U}-87$ cells treated with berberine or $\mathrm{As}_{2} \mathrm{O}_{3}$, and cotreated with $\mathrm{As}_{2} \mathrm{O}_{3}$ and berberine for $24 \mathrm{~h}$. C6 glioma cells $(\mathrm{A})$ and human U-87 cells (B) were incubated with I, 2, 5, I0, and $20 \mu \mathrm{M}$ berberine or $\mathrm{As}_{2} \mathrm{O}_{3}$ for $24 \mathrm{~h}$ and the proportion of surviving cells was determined using the MTT assay as described in Methods. (C) C6 glioma and human U-87 cells were co-treated with $5 \mu \mathrm{M} \mathrm{As}_{2} \mathrm{O}_{3}$ and I, 2, 5, I0, and $20 \mu \mathrm{M}$ berberine for 24 $\mathrm{h}$, and the cell growth was determined as described in Methods. Control cells were treated with $\mathrm{As}_{2} \mathrm{O}_{3}$ alone. The experiments were performed in triplicate and data are presented as means \pm SD. * and ** indicate means that are significantly different when compared to the control group of $\mathrm{C} 6$ with $P<0.05$ and $P<0.0 \mathrm{I}$, respectively. \# and \#\# indicate means that are significantly different when compared to the control group of $U-87$ with $P<0.05$ and $P<0.01$, respectively. 


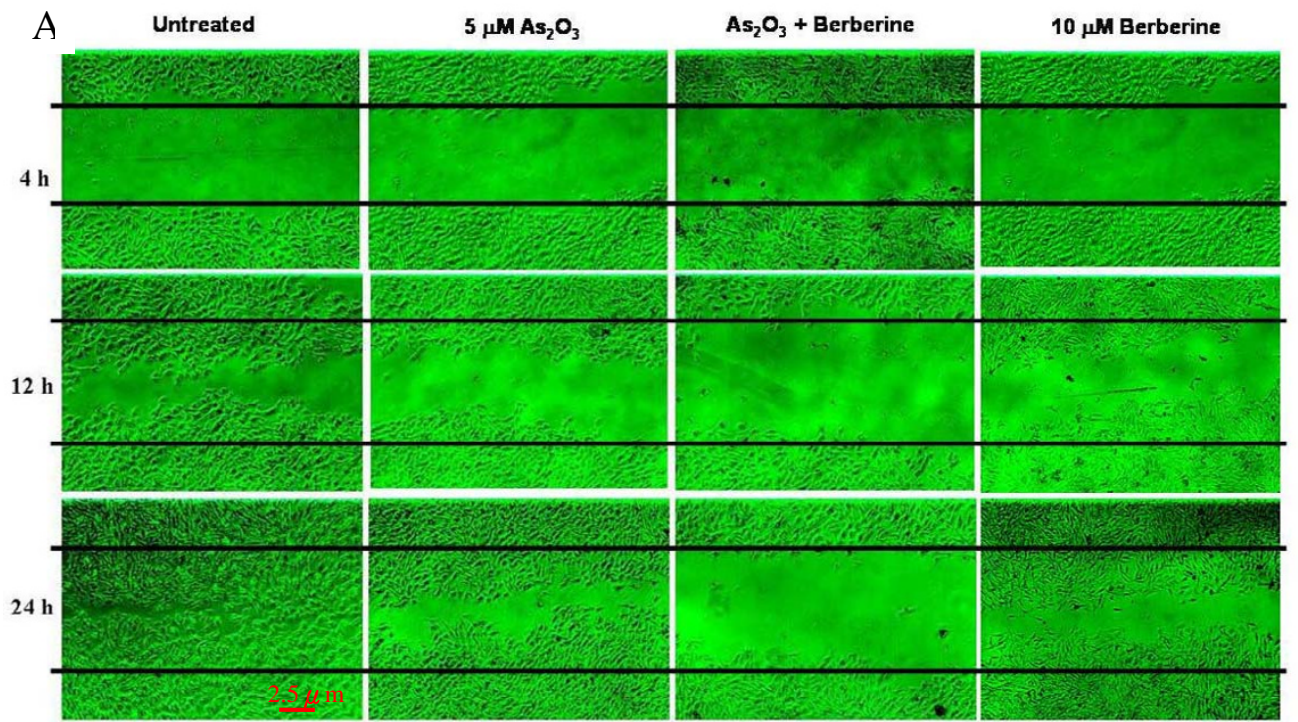

$\mathrm{B}$

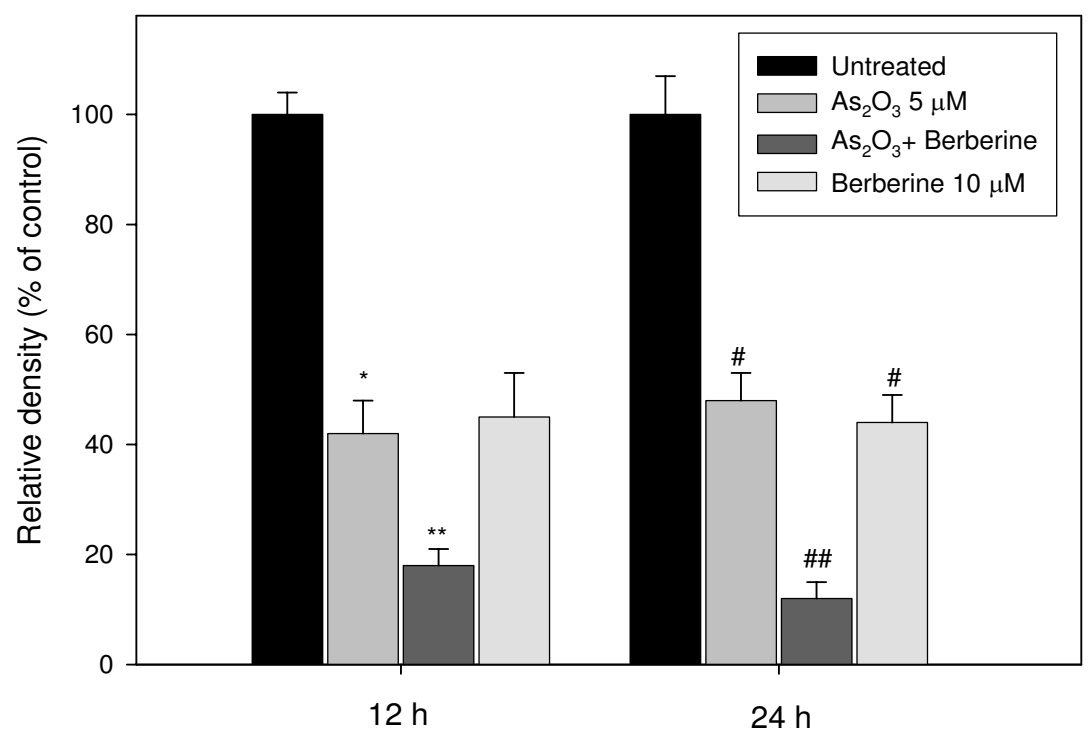

Figure 2

Determination of the effects of berberine- $\mathrm{As}_{2} \mathrm{O}_{3}$ co-treatment on cell migration and growth using the scratchwound assay. $\mathrm{C} 6$ glioma cells were incubated with $5 \mu \mathrm{M} \mathrm{As} \mathrm{O}_{2}$ or $10 \mu \mathrm{M}$ berberine alone and with $5 \mu \mathrm{MAs} \mathrm{A}_{2}$ and $10 \mu \mathrm{M}$ berberine for 4, 12, and $24 \mathrm{~h}$ and the migration was visualized as described in Methods (A). The percentage of surface area filled by the $\mathrm{C} 6$ cells was subsequently quantified by densitometric analyses relative to that of the control which was set at $100 \%$ as shown in the graph (B). Data are presented as means \pm SD based on three independent experiments. * and ** indicate means that are significantly different when compared to the control group of $12 \mathrm{~h}$ incubation with $P<0.05$ and $P<0.0 \mathrm{I}$, respectively. \# and \#\# indicate means that are significantly different when compared to the control group of $24 \mathrm{~h}$ incubation with $P<0.05$ and $P<0.01$, respectively. 


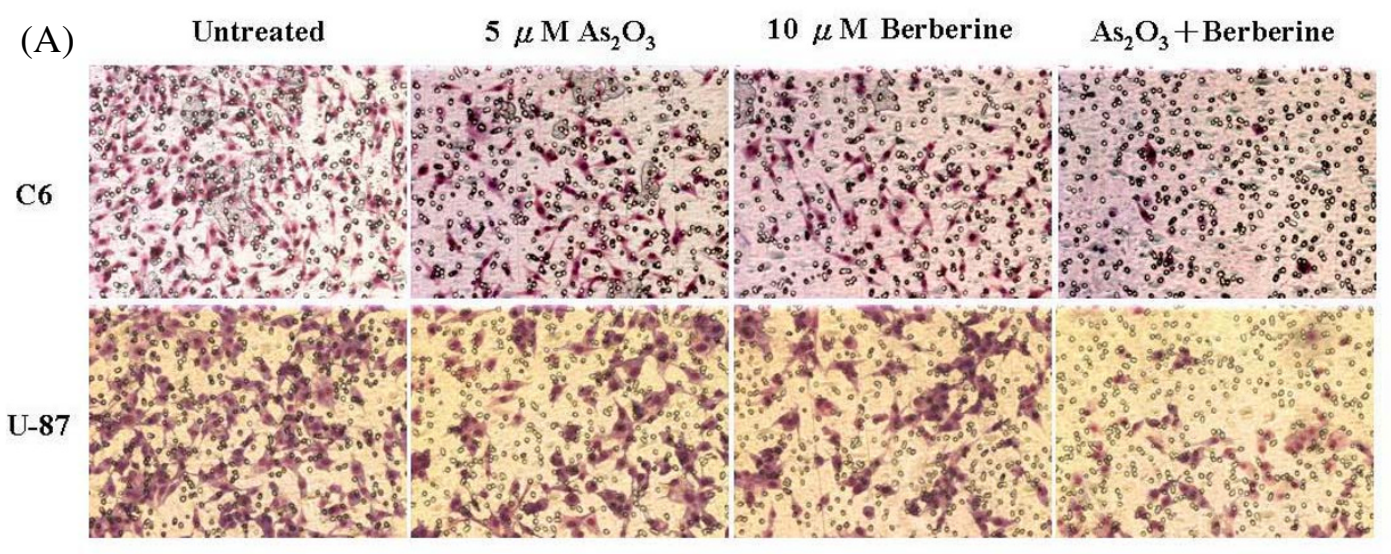

(B)

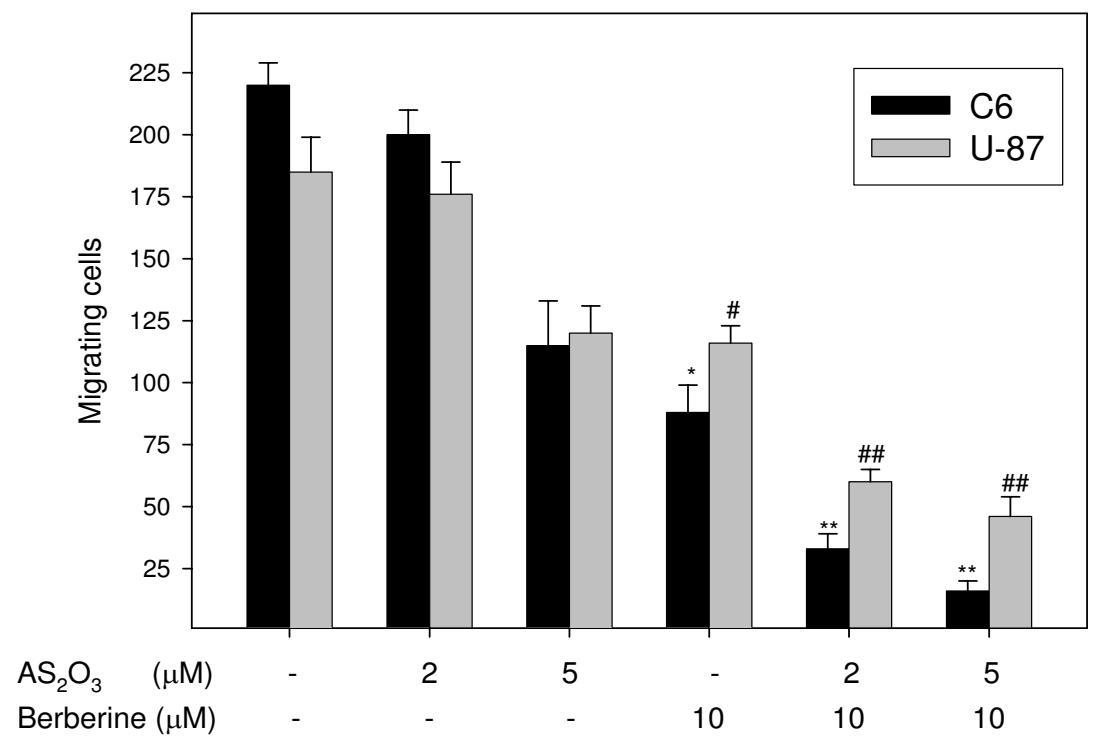

Figure 3

Effect of berberine on $\mathrm{As}_{2} \mathrm{O}_{3}$-inhibited motility of $\mathrm{C} 6$ glioma and $\mathrm{U}-87$ cells. (A) Cells were incubated with $5 \mu \mathrm{M}$ $\mathrm{As}_{2} \mathrm{O}_{3}$ or $10 \mu \mathrm{M}$ berberine and co-treated with $5 \mu \mathrm{M}$ and $10 \mu \mathrm{M}$ berberine for $24 \mathrm{~h}$. The lower and upper chemotaxis cells were separated by a polycarbonate membrane. Microscopy images detected cells that migrated into the inner membrane. Magnification: $\times 200$. The cell migration was quantified by counting the number of cells that migrated into the inner membrane (B). Control cells remained untreated. The experiments were performed in triplicate and data are presented as means \pm SD. $*$ and ** indicate means that are significantly different when compared to the control group of $C 6$ with $P<0.05$ and $P<0.01$, respectively. \# and \#\# indicate means that are significantly different when compared to the control group of $U-87$ with $P<0.05$ and $P$ $<0.0$ I, respectively. 


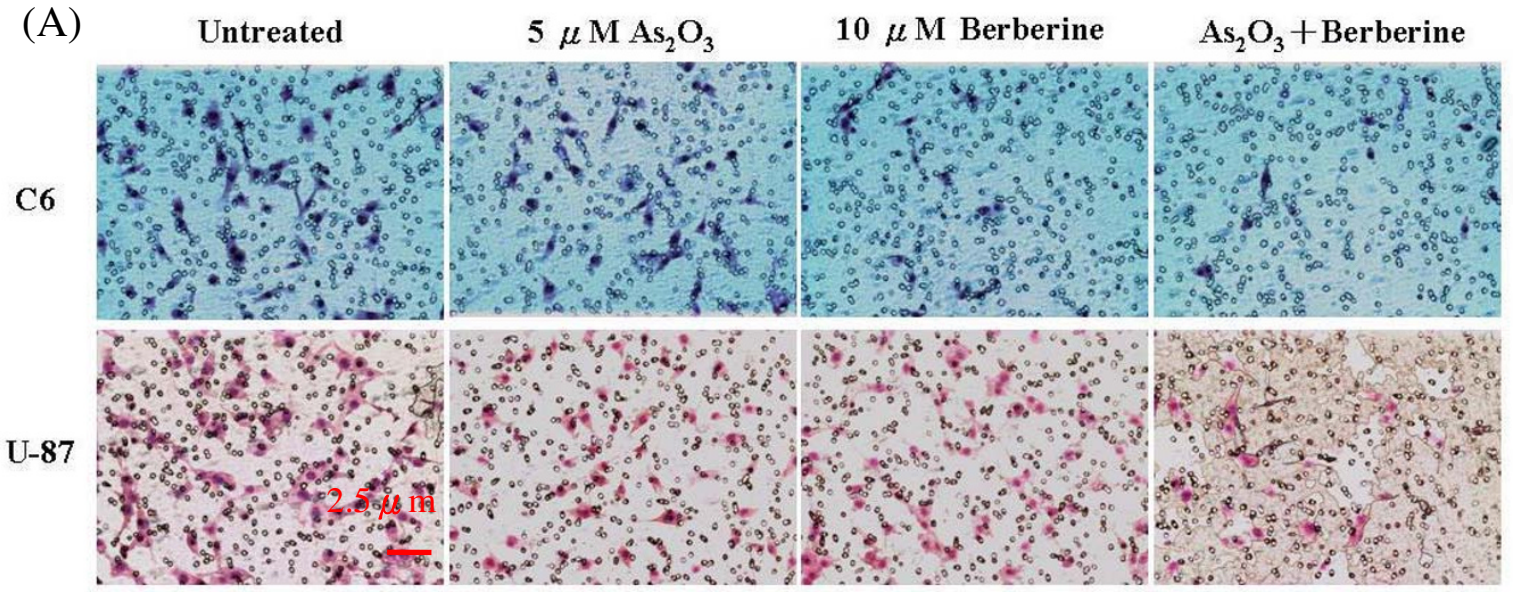

(B)

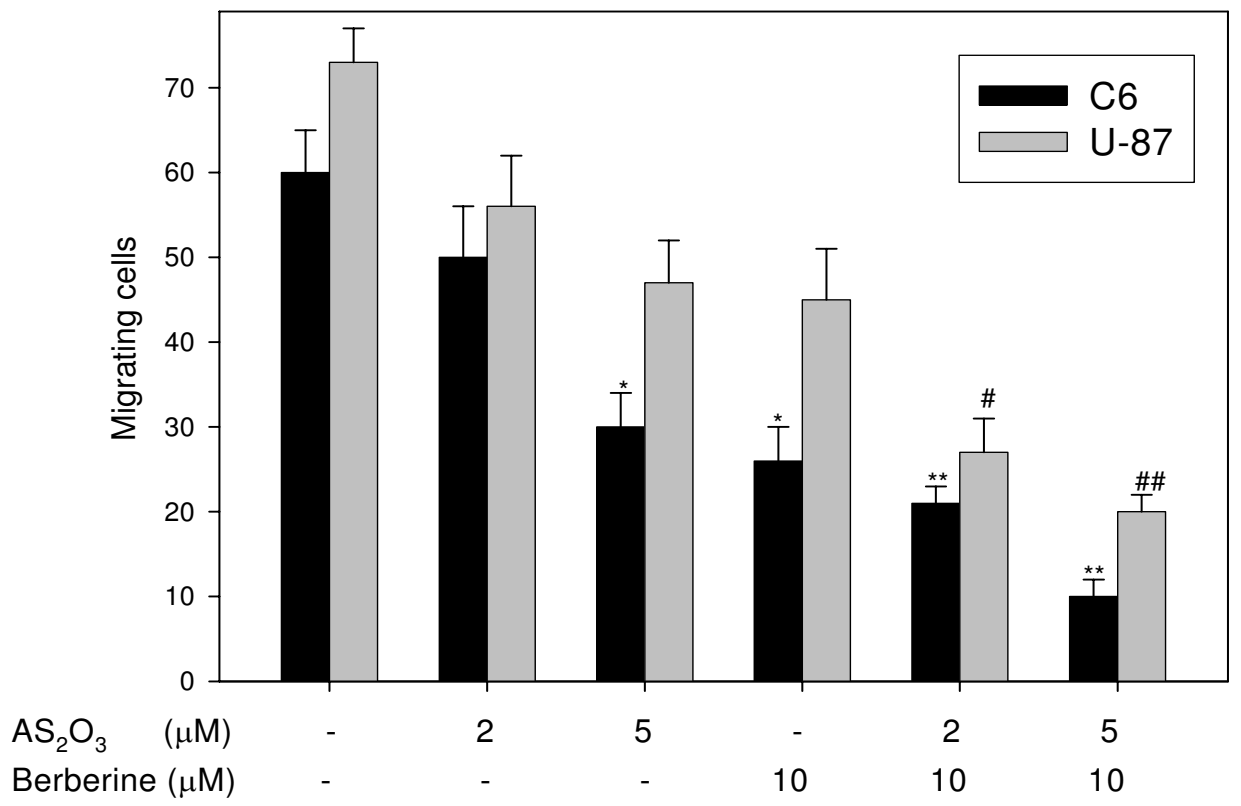

\section{Figure 4}

Effect of berberine on $\mathrm{As}_{2} \mathrm{O}_{3}$-inhibited invasiveness of $\mathbf{C 6}$ glioma and U-87 cells. (A) Cells were incubated with $5 \mu \mathrm{M}$ $\mathrm{As}_{2} \mathrm{O}_{3}$ or $10 \mu \mathrm{M}$ berberine and co-treated with $5 \mu \mathrm{M}$ and $10 \mu \mathrm{M}$ berberine for $24 \mathrm{~h}$. Invasion through a layer of Matrigel was determined by a Boyden Chamber method as described in Methods. The invasiveness was quantified and is presented in the graph (B). Control cells remained untreated. The experiments were performed in triplicate and data are presented as means \pm SD. * and ** indicate means that are significantly different when compared to the control group of $C 6$ with $P<0.05$ and $P<$ 0.01 , respectively. \# and \#\# indicate means that are significantly different when compared to the control group of U-87 with $P<$ 0.05 and $P<0.01$, respectively. 

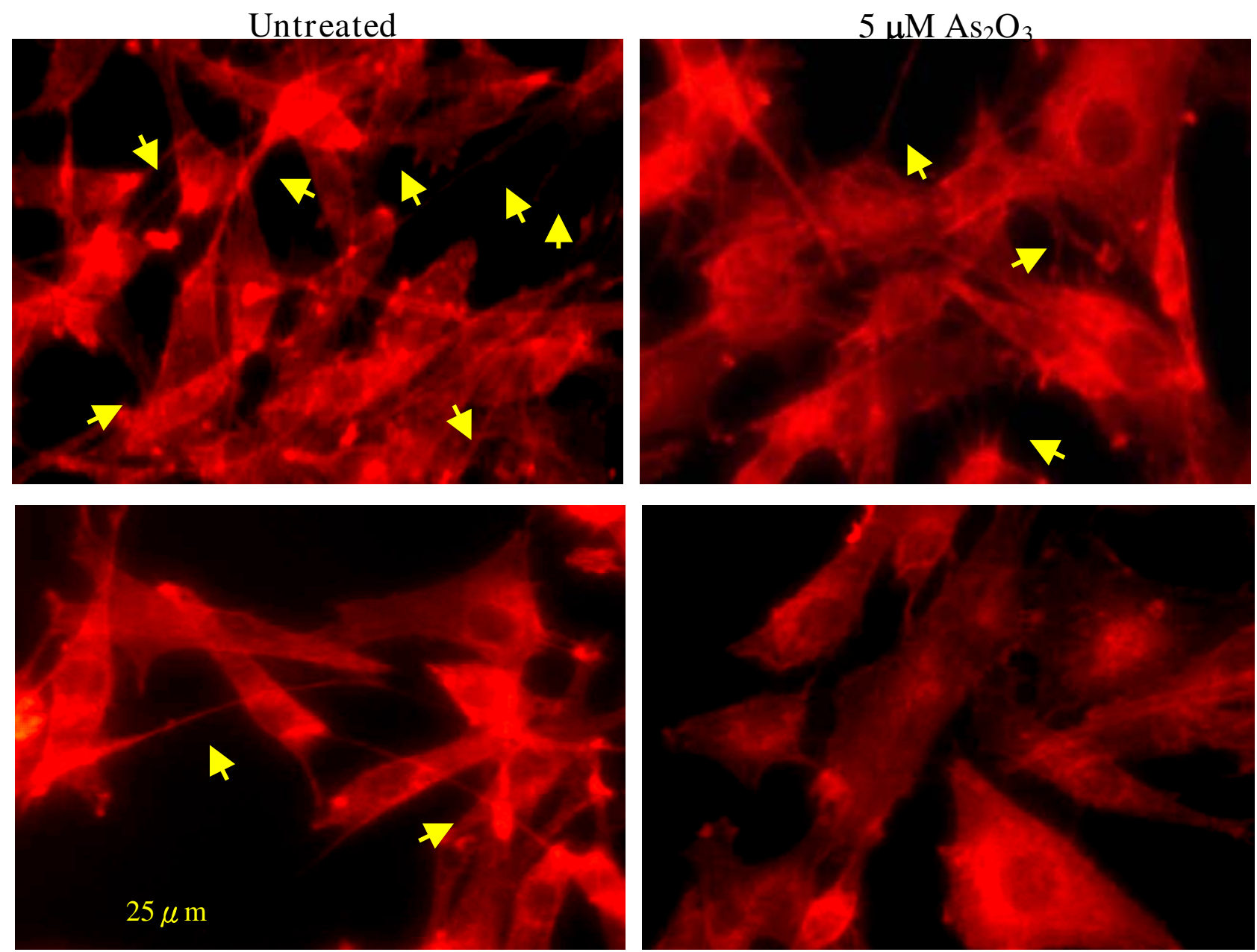

$10 \mu \mathrm{M}$ Berberine

$\mathrm{As}_{2} \mathrm{O}_{3}+$ Berberine

\section{Figure 5}

Actin rearrangements in $\mathbf{C 6}$ glioma cells treated with $\mathrm{As}_{2} \mathrm{O}_{3}$ or berberine. $\mathrm{C} 6$ glioma cells were incubated with 5 $\mu \mathrm{M} \mathrm{As}_{2} \mathrm{O}_{3}$ or $10 \mu \mathrm{M}$ berberine and co-treated with $5 \mu \mathrm{M}$ and $10 \mu \mathrm{M}$ berberine for $24 \mathrm{~h}$. Actin rearrangements were visualized by immunolocalization using anti-F-actin antibodies as described in Methods. Co-treatment with berberine and $\mathrm{As}_{2} \mathrm{O}_{3}$ resulted in actin (arrows) impolarization at the edges of the cell. Actin ruffing at the edges of the elongated cells was also observed and indicative of increased migration.

(Figure 4), which enhanced the dose-response relationship.

An important characteristic of advanced cancer development metastasis, during which cancer cells migrate to other tissues and organs, is the rearrangement of the cytoskeleton of migrating cells [45]. The cytoskeleton changes in C6 glioma cells treated with $5 \mu \mathrm{M} \mathrm{As}{ }_{2} \mathrm{O}_{3}$ or 10 $\mu \mathrm{M}$ berberine, and co-treated with $\mathrm{As}_{2} \mathrm{O}_{3}$ and berberine, were visualized using $\mathrm{F}$-actin specific antibodies that bind to F-actin (filopodia; yellow arrow head, Figure 5), and revealed structural rearrangements in the actin cytoskele- ton that were observed upon cell spreading and ruffling (Figure 5).

\section{Berberine prevents cytosol-to-membrane translocation of PKC $\alpha$ and PKC $\varepsilon$ isoenzymes}

Recent studies report that overexpressed or hyperactive $\mathrm{PKC}$ is among the most distinguishing characteristics of central nervous system tumors [46]. The PKC $\alpha$ and PKCE activity levels seem to be increased in malignant gliomas and mechanisms related to tumor cell invasion, and metastasis is activated $[47,48]$. To further evaluate the effect of chemotherapeutic agents such as $\mathrm{As}_{2} \mathrm{O}_{3}$ in the 


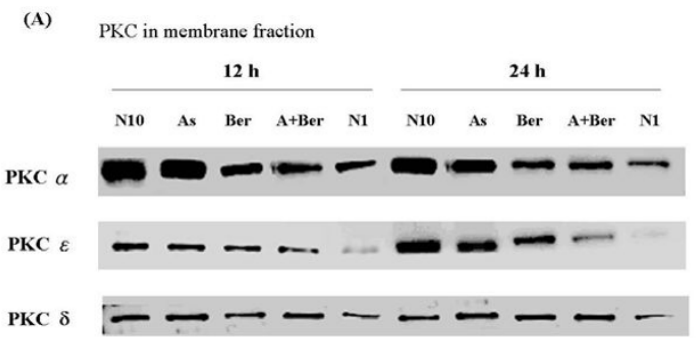

(B) PKC in cytosol fraction

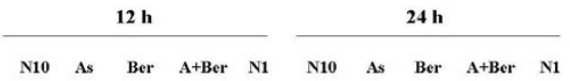
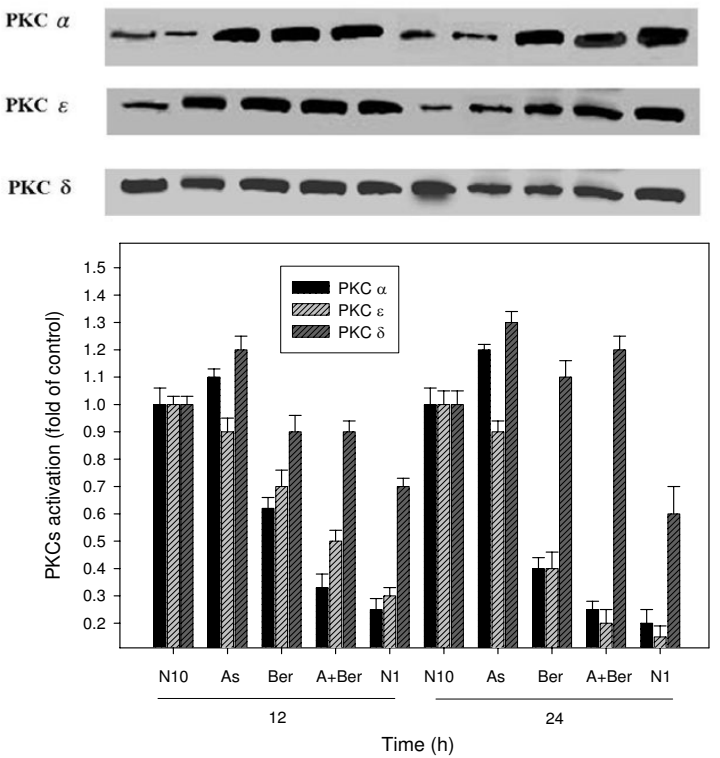

(C) Nuclear fraction

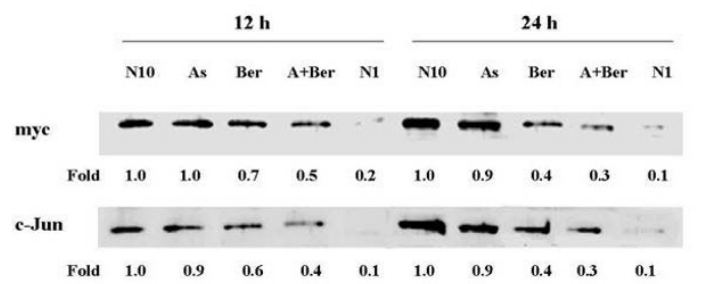

\section{Figure 6}

Effect of berberine and $\mathrm{As}_{2} \mathrm{O}_{3}$ on the translocation of $\mathrm{PKC} \alpha$ and $\mathrm{PKC} \varepsilon$. C6 glioma cells were incubated for 12 and 24 h with $10 \mu \mathrm{M}$ berberine (Ber) or $5 \mu \mathrm{MAs} \mathrm{A}_{2} \mathrm{O}_{3}$ (As), and with $10 \mu \mathrm{M}$ berberine and $5 \mu \mathrm{M} \mathrm{As} \mathrm{O}_{3}$ (A+Ber) (A, B). Cytosolic (B) and membrane fractions (A) were evaluated for the presence of PKC $\alpha$ and $P K C \varepsilon$ by Western blotting. Control cells were not treated in the presence of $10 \%$ Fetal Calf Serum (FCS) (NI0). Cells that were not exposed to agents were used as negative control in the presence of $1 \%$ FCS $(\mathrm{NI})$. The PKC levels in the respective fractions were quantified and normalized taking the $\beta$-actin value as a loading control as presented in the graph. Each value is the relative ratio of PKCs membrane to cytosol fraction (presumably, the ratio of untreated control is I). In addition, the nuclear protein fractions were evaluated for the presence of myc and c-jun, two transcription factors that act downstream of PKC, by Western blotting (C). The quantitative data were presented as three repeats from one independent experiment and indications are in panel $A$. The intensity of the protein bands was quantified and the level relative to the NIO control band was presented (fold). 

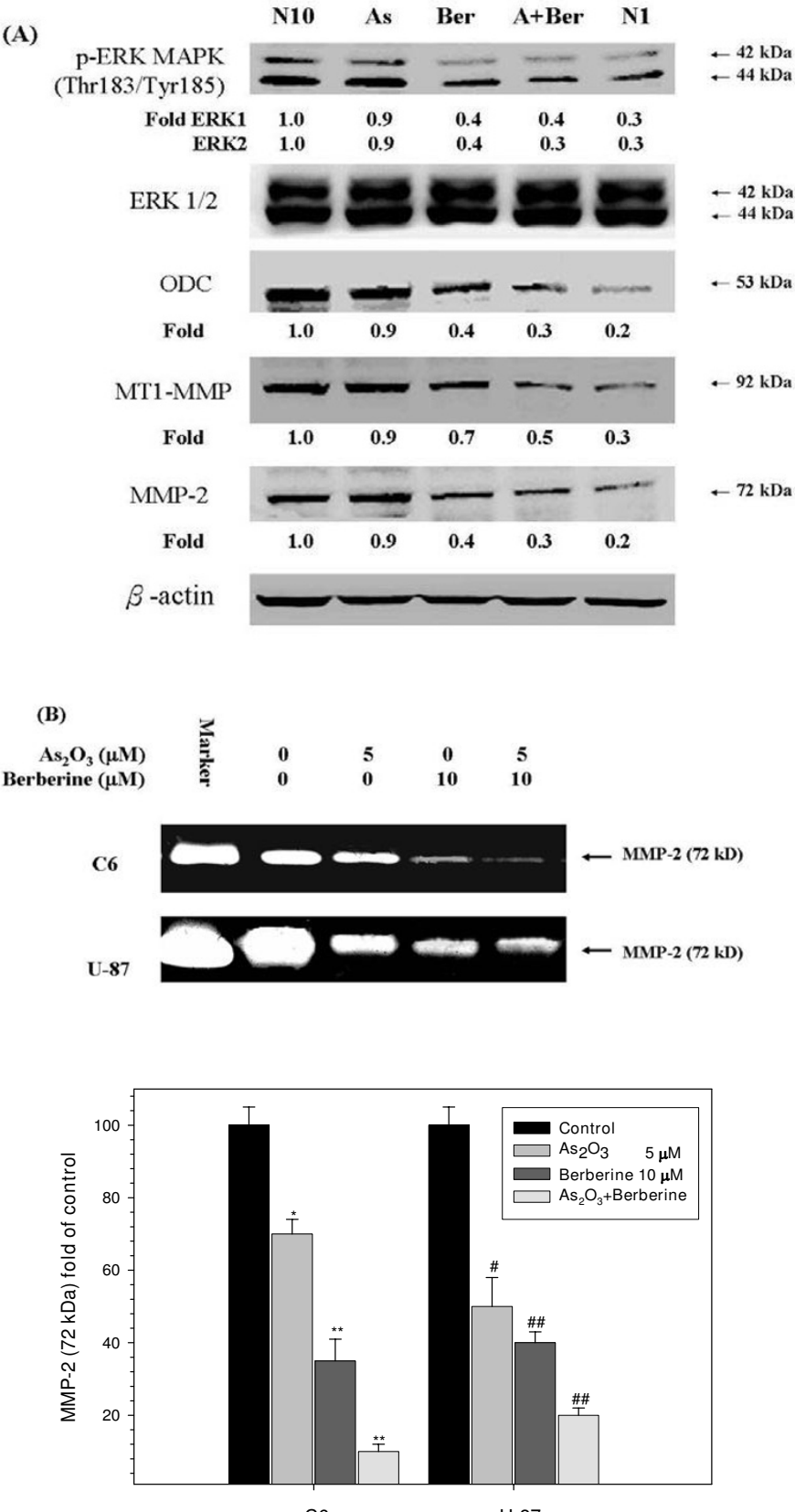

C6

U-87

\section{Figure 7}

Berberine and $\mathrm{As}_{2} \mathrm{O}_{3}$ inhibit the phosphorylation of ERK and decrease the ornithine decarboxylase (ODC), MT I-MMP, and MMP2 protein levels. C6 glioma cells were incubated for $24 \mathrm{~h}$ with $10 \mu \mathrm{M}$ berberine (Ber) or $5 \mu \mathrm{M} \mathrm{As}_{2} \mathrm{O}_{3}$ (As), and with $10 \mu \mathrm{M}$ berberine and $5 \mu \mathrm{M} \mathrm{As} s_{2} \mathrm{O}_{3}(\mathrm{~A}+\mathrm{Ber})$. Total cell lysates were prepared and subjected to Western blot analysis. Protein levels of phosphorylated ERKI/ERK2 and non-phosphorylated ERKI/ERK2, and ODC, MTI-MMP and MMP2 were detected using the respective monoclonal antibodies $(A)$. The condition serum free media were collected for gelatin zymography analysis from C6 glioma and U-87 cells. Determined activities of these proteins were subsequently quantified by densitometric analysis with the value of controls set at 100\% as shown in the graph. The quantitative data were presented as the mean of three repeats from one independent experiment. Other data in this figure is presented as mean \pm SD of three independent experiments. * and $* *$ indicate means that are significantly different when compared to the control group of $\mathrm{C} 6$ with $P<0.05$ and $P<0.0$ I, respectively. \# and \#\# indicate means that are significantly different when compared to the control group of $U-87$ with $P<0.05$ and $P<0.01$, respectively. 
PKC signaling pathway, we examined whether berberine enhanced $\mathrm{As}_{2} \mathrm{O}_{3}$-mediated modulation of the translocation of PKC $\alpha$ and PKC $\varepsilon$ isoenzymes using Western blot analyses. Remarkably, $10 \mu \mathrm{M}$ berberine had a dramatic effect on the cytosol-to-membrane translocation of PKC $\alpha$ and PKCE after 12 and $24 \mathrm{~h}$ incubation (Figures 6A and $6 \mathrm{~B})$. Furthermore, the combined treatment with $\mathrm{As}_{2} \mathrm{O}_{3}$ and berberine resulted in inhibition of the activation of PKC $\alpha$ and $\mathrm{PKC} \varepsilon$, but not PKC $\delta$ (Figures 6A and 6B), as compared to the negative control (1\% fetal calf serum). Once activated, PKC can transmit signals to the nucleus via MAPK-mediated cascades and activated ERKs can induce the production of transcription factors including myc and jun $[49,50]$. To further investigate the effect of $\mathrm{As}_{2} \mathrm{O}_{3}$-berberine co-treatment on PKC-mediated signaling, the nuclear levels of those transcription factors were determined. Figure 6C illustrates that the levels of myc and jun in nuclei were significantly reduced after treatment with $10 \mu \mathrm{M}$ berberine in the presence of $5 \mu \mathrm{M} \mathrm{As}_{2} \mathrm{O}_{3}$ for $24 \mathrm{~h}$.

\section{Inhibitory effect of berberine and $\mathrm{A}_{2} \mathrm{O}_{3}$ on the activation of MMP-2 associated with invasiveness of glioma cells via interference with PKCs}

Activated PKCs enable the expression of genes encoding enzymes that are involved in cell proliferation and invasion $[30,46,50]$ such as the gene encoding ornithine decarboxylase (ODC), an enzyme that plays a role in cell transformation and excessive extracellular matrix degradation [51]. Because the observations presented above strongly suggest that berberine and $\mathrm{As}_{2} \mathrm{O}_{3}$ act via the inhibition of PKC signaling, the activation of three PKCdependent key factors was examined by Western blot analyses. These experiments demonstrated that the berberine- $\mathrm{As}_{2} \mathrm{O}_{3}$-mediated enhanced suppression of ERK phosphorylation led to a decrease of the levels of ODC, MT1-MMP, and MMP-2 in C6 glioma cells to values that resembled those observed in negative controls (Figure 7A).

Extracellular matrix breakdown is pivotal for cellular invasion, indicating that matrix-degrading proteinases are essential for tumor cell metastasis [28]. Therefore, we determined the activity of MMP-2 by gelatin zymography after $24 \mathrm{~h}$ incubation with $5 \mu \mathrm{M} \mathrm{As}{ }_{2} \mathrm{O}_{3}$ and $10 \mu \mathrm{M}$ berberine in C6 or U-87 glioma cells. A significant decrease in the activity of MMP-2 was observed after 24 h exposure to $\mathrm{As}_{2} \mathrm{O}_{3}$ and berberine (Figure $7 \mathrm{~B}$ ), likely explaining why co-treatment with berberine and $\mathrm{As}_{2} \mathrm{O}_{3}$ strongly affects glioma cell migration and invasiveness.

\section{Discussion}

Berberine is a naturally occurring alkaloid that exhibits various pharmacological effects. Clinical trials and studies in animal model systems have demonstrated that berber- ine has anti-microbial, vulnerary, cardiovascular [52], immunostimulatory, anti-hemorrhagic, and anti-inflammatory properties, as well as selective repression of the growth of several carcinoma cells without causing cytotoxicity in the liver $[32,53]$. Control experiments using rat primary cortical astrocytes illustrated that treatment with $5 \mu \mathrm{M} \mathrm{As}{ }_{2} \mathrm{O}_{3}$ or $20 \mu \mathrm{M}$ berberine, or co-treatment with 5 $\mu \mathrm{M} \mathrm{As}{ }_{2} \mathrm{O}_{3}$ and $20 \mu \mathrm{M}$ berberine, did not cause any detectable toxic effects (data not shown). However, the effect of berberine on migration and invasion of glioma cells at relatively low concentrations was striking, particularly in the presence of $\mathrm{As}_{2} \mathrm{O}_{3}$. Most interesting was the enhanced effect that $\mathrm{As}_{2} \mathrm{O}_{3}$-berberine co-treatment had on glioma cell migration and invasiveness, as $10 \mu \mathrm{M}$ berberine significantly lowered the concentration of $\mathrm{As}_{2} \mathrm{O}_{3}$ required to obtain an antiproliferation effect on human glioma cells. This dose-lowering effect, unique to this study, could not be exploited in other studies in which tumor cells were treated with either berberine $[37,38]$ or $\mathrm{As}_{2} \mathrm{O}_{3}[14]$.

$\mathrm{As}_{2} \mathrm{O}_{3}$ has considerable efficacy in the treatment of relapsed APL, inducing partial differentiation and promoting apoptosis of malignant promyelocytes [54,55]. The mechanisms underlying $\mathrm{As}_{2} \mathrm{O}_{3}$-mediated apoptosis are only beginning to be understood, but appear to be distinct from those employed by traditional cytotoxic agents. The intracellular glutathione redox system represents the best-characterized mechanism of $\mathrm{As}_{2} \mathrm{O}_{3}$ sensitivity $[39,55]$. These findings underscore the importance of understanding how differences in cell types or cellular environments might affect the action of $\mathrm{As}_{2} \mathrm{O}_{3}$. A determination of the factors that mediate sensitivity to $\mathrm{As}_{2} \mathrm{O}_{3}$ will allow the use of this agent in such a way as to optimize therapeutic outcomes and minimize toxicity in the treatment of various malignancies. To date, evidence that the development of resistance to chemotherapy affects the response to arsenic is scarce. Thus, $\mathrm{As}_{2} \mathrm{O}_{3}$ represents a novel chemotherapeutic agent worth for continuous investigation, particularly when used in combination with another agent such as berberine that exhibits an enhanced inhibitory effect, which allows lowering the working $\mathrm{As}_{2} \mathrm{O}_{3}$ concentration.

In previous studies, cell movement through tissue has been observed to play a primary role in cancer progression. This process requires a series of distinct, but concerted, biological events in which the actin cytoskeleton plays an essential role. These events include tumor cell attachment to extracellular matrix (ECM) components, and the degradation of the matrix by tumor cell-associated proteases $[28,56]$. It has long been known that in most cell types, one or more PKC isoforms influence the morphology of the F-actin cytoskeleton and overexpressed or hyperactive PKC is among the most distinguished characteristics of malignant central nervous 
system tumors including C6 or U-87 glioma cells [46,57]. In certain tumors, a reduction in PKC $\alpha$ and PKC $\varepsilon$ expression merely results in growth inhibition, so that a cytotoxic effect requires induction of apoptosis through activation of PKC $\delta$ [58]. Exposure of C6 cells in the presence of $\mathrm{As}_{2} \mathrm{O}_{3}$ to berberine exhibits a significant effect characterized by alterations in cell shape and actin cytoskeleton changes. Moreover, the data presented herein suggests that the cytosol-to-membrane translocation of PKC $\alpha$ and PKCe is slightly suppressed by $\mathrm{As}_{2} \mathrm{O}_{3}$ and this inhibition is enhanced upon co-treatment with berberine for $24 \mathrm{~h}$, although berberine itself did cause inactivation of PKC $\alpha$ and PKC $\varepsilon$ but not PKC $\delta$. Similar to the action of the PKC signaling pathway, the expression on myc, c-fos, ODC, MT1-MMP, and MMP-2 as well as the phosphorylation of ERK by co-treatment could be abolished.

Arsenic-containing compounds have been used for the treatment of cancer for hundreds of years in both traditional Chinese and Western medicine [59]. Only a few reports are available that describe the underlying mechanisms of the action of specific chemotherapeutic agents used to treat cancer metastasis. In this study, we demonstrate for the first time that berberine sensitizes malignant glioma cells for $\mathrm{As}_{2} \mathrm{O}_{3}$-mediated suppression of migration and invasiveness likely via decreased PKC signaling and MMP-2 activation in the extracellular matrix. The involvement of PKC signaling is not yet undoubtedly proven, as the effect of $\mathrm{As}_{2} \mathrm{O}_{3}$ and berberine on glioma tumor cells overexpressing PKC $\alpha$ and PKC $\varepsilon$ remains to be investigated. Furthermore, we tried to investigate the dual effect that berberine has on glioma cells. First, berberine exhibits an anti-oxidant activity thereby protecting healthy cells against the $\mathrm{As}_{2} \mathrm{O}_{3}$-induced production of toxic reactive oxygen species $[5,33,53]$. Second, berberine may reduce the $\mathrm{As}_{2} \mathrm{O}_{3}$-mediated carcinogenic effect by inhibiting PKC $\alpha$ translocation in the mouse epidermal JB6 cells [60]. This dual effect is particularly important in a co-treatment with $\mathrm{As}_{2} \mathrm{O}_{3}$ because $\mathrm{As}_{2} \mathrm{O}_{3}$ is a carcinogen [10]; however, upon co-treatment with berberine, the working concentration of $\mathrm{As}_{2} \mathrm{O}_{3}$ can be significantly lowered, while, in addition, healthy cells are protected against possible adverse side effects caused by exposure to $\mathrm{As}_{2} \mathrm{O}_{3}$.

Invasion and metastasis inhibitors are effective (alone or in combination therapy with other agents) in restraining new tumor formation when earlier therapy or surgery has failed. Therefore, it appears that a combination of $\mathrm{As}_{2} \mathrm{O}_{3}$ and berberine inhibits the proliferation and invasion of glioma cells. Although future studies are required to experimentally link the various pathways that appear to be involved in the berberine/ $/ \mathrm{As}_{2} \mathrm{O}_{3}$-mediated suppression of glioma cell migration and invasiveness, to better understand the molecular mechanisms that occur in the extra- cellular matrix surrounding glioma cells during tumor metastasis, to investigate novel methods to specifically deliver, for instance, berberine and $\mathrm{As}_{2} \mathrm{O}_{3}$ to glioma tumor cells, and to investigate the effectiveness and safeness of berberin- $\mathrm{As}_{2} \mathrm{O}_{3}$ co-treatment in a clinical setting, this study forms the basis for the design of novel therapeutic strategies to ameliorate and prevent human glioma formation. Furthermore, the observations presented herein suggest that (i) berberine should be further considered as a complementary antitumor treatment in clinical applications, and (ii) application of berberine has a dual ameliorating effect as it enhances the antitumor effect of $\mathrm{As}_{2} \mathrm{O}_{3}$ while it allows a lower working concentration of $\mathrm{As}_{2} \mathrm{O}_{3}$ by which its global carcinogenic effect to healthy cells, mediated by the fact that elemental arsenic can enter the cerebrospinal fluid [61], is diminished.

\section{Conclusion}

We demonstrate that berberine enhances inhibition of the migration and invasiveness of glioma cells mediated by $\mathrm{As}_{2} \mathrm{O}_{3}$, or, in other words, that a concentration as low as $10 \mu \mathrm{M}$ of the natural compound berberine is sufficient to significantly lower the $\mathrm{As}_{2} \mathrm{O}_{3}$ concentration needed to obtain its antiproliferation effect in a rat and human malignant glioma cell line. While not yet undoubtedly proven, our results suggest that this effect is likely mediated by the disturbance in PKC signaling which leads to a reduction of the level of MMP-2, a metalloprotease involved in cancer cell migration during metastasis.

\section{List of abbreviations}

APL, acute promyelocytic leukemia; ECM, extracellular matrix; ERK, extracellular signal-regulated kinase; MAPK, mitogen-activated protein kinase; MMP, matrix metalloproteinase; MT1-MMP, membrane type-1 matrix metalloproteinase; ODC, ornithine decarboxylase; PBS, phosphate-buffered saline; $\mathrm{PKC}$, protein kinase $\mathrm{C}$

\section{Competing interests}

The author(s) declare that they have no competing interests.

\section{Authors' contributions}

LTH conceived, designed, and performed the study, and prepared the manuscript. KHC performed data analysis, and provided cell lines and technical assistance to LTH. Chou FP supervised work and manuscript review. LFJ, supervised the entire study and manuscript revision.

\section{Acknowledgements}

The study was supported by a grant of the Taichung Veterans General Hospital (TCVGH-95370IA).

The author would like to thank Dr. Chun-Jung Chen for helping to perform controlexperiments using rat primary cortical astrocytes. 
† These authors contributed equally to this work.

\section{References}

I. Rego EM, He LZ, Warrell RP, Wang ZG, Pandolfi PP: Retinoic acid (RA) and As2O3 treatment in transgenic models of acute promyelocytic leukemia (APL) unravel the distinct nature of the leukemogenic process induced by the PML-RARalpha and PLZF-RARalpha oncoproteins. Proc Natl Acad Sci USA 2000 97:10173-10178.

2. Wang ZY: Arsenic compounds as anticancer agents. Cancer Chemother Pharmacol 200I, 48(Suppl I):S72-76.

3. Bachleitner-Hofmann T, Kees M, Gisslinger H: Arsenic trioxide: acute promyelocytic leukemia and beyond. Leuk Lymphoma 2002, 43:1535-1540.

4. Miller WH, Schipper HM, Lee JS, Singer J, Waxman S: Mechanisms of action of arsenic trioxide. Cancer Res 2002, 62:3893-3903.

5. Berenson JR, Yeh HS: Arsenic compounds in the treatment of multiple myeloma: a new role for a historical remedy. Clin Lymphoma Myeloma 2006, 7:192-198.

6. Li YM, Broome JD: Arsenic targets tubulins to induce apoptosis in myeloid leukemia cells. Cancer Res 1999, 59:776-780.

7. Akao $Y$, Yamada $H$, Nakagawa $Y$ : Arsenic-induced apoptosis in malignant cells in vitro. Leuk Lymphoma 2000, 37:53-63.

8. Murgo AJ: Clinical trials of arsenic trioxide in hematologic and solid tumors: overview of the National Cancer Institute Cooperative Research and Development Studies. Oncologist 200I, 6(Suppl 2):22-28.

9. Zhang TD, Chen GQ, Wang ZG, Wang ZY, Chen S], Chen Z: Arsenic trioxide, a therapeutic agent for APL. Oncogene 200I, 20:7|46-7I53

10. Bode AM, Dong Z: The paradox of arsenic: molecular mechanisms of cell transformation and chemotherapeutic effects. Crit Rev Oncol Hematol 2002, 42:5-24.

II. Chen Z, Chen GQ, Shen ZX, Sun GL, Tong JH, Wang ZY, Chen S: Expanding the use of arsenic trioxide: leukemias and beyond. Semin Hematol 2002, 39:22-26.

12. Halicka HD, Smolewski P, Darzynkiewicz Z, Dai W, Traganos F: Arsenic trioxide arrests cells early in mitosis leading to apoptosis. Cell Cycle 2002, I:20I-209.

13. Wei LH, Lai KP, Chen CA, Cheng CH, Huang YJ, Chou CH, Kuo ML Hsieh CY: Arsenic trioxide prevents radiation-enhanced tumor invasiveness and inhibits matrix metalloproteinase- 9 through downregulation of nuclear factor kappaB. Oncogene 2005, 24:390-398.

14. Cheung WMW, Chu PWK, Kwong YL: Effects of arsenic trioxide on the cellular proliferation, apopsosis and differentiation of human neuroblastoma cells. Cancer Lett 2007, 246: I22-128.

15. Ratnaike RN: Acute and chronic arsenic toxicity. Postgrad Med J 2003, 79:39I-396.

16. Couldwell WT, Antel JP, Yong VW: Protein kinase $\mathbf{C}$ activity correlates with the growth rate of malignant gliomas: Part II. Effects of glioma mitogens and modulators of protein kinase C. Neurosurgery 1992, 31:717-724.

17. da Rocha $A B$, Mans DR, Bernard EA, Ruschel C, Logullo AF, Wetmore LA, Leyva A, Schwartsmann G: Tamoxifen inhibits particulate-associated protein kinase $C$ activity, and sensitises cultured human glioblastoma cells not to etoposide but to gamma-radiation and BCNU. Eur J Cancer 1999, 35:833-839.

18. Hofmann J: Protein kinase $\mathbf{C}$ isozymes as potential targets for anticancer therapy. Curr Cancer Drug Targets 2004, 4: I25-I 46.

19. Mackay HJ, Twelves C]: Protein kinase C: a target for anticancer drugs? Endocr Relat Cancer 2003, 10:389-396.

20. Cho K-K, Mikkelsen T, Lee YJ, Jiang F, Chopp M, Rosenblum ML: The role of protein kinase $\mathrm{C} \alpha$ in $\mathbf{U}-87$ glioma invasion. Int ] Dev Neuroscience 1999, 17(5-6):447-46I.

21. Lahn MM, Sundell KL, Paterson BM: The role of protein kinase C$\alpha$ in malignancies of the nervous system and implications for the clinical development of the specific PKC- $\alpha$ inhibitor apprinocarsen. Oncol Rep 2004, I I:5 I 5-522.

22. Zhang W, Law RE, Hinton DR, Couldwell WT: Inhibition of human malignant glioma cell motility and invasion in vitro by hypericin, a potent protein kinase C inhibitor. Cancer Lett 1997, I20:31-38.

23. Masur K, Lang K, Niggemann B, Zanker KS, Entschladen F: High PKC $\alpha$ and low E-cadherin expression contribute to high migra- tion activity of colon carcinoma cells. Mol Biol Cell 200I, 12:1973-1982

24. Serova M, Ghoul A, Benhadji KA, Cvitkovic E, Faivre S, Calvo F, Lokiec F, Raymond E: Preclinical and clinical development of novel agents that target the protein kinase C family. Semin Oncol 2006, 33:466-478.

25. Koivunen J, Aaltonen V, Koskela S, Lehenkari P, Laato M, Peltonen J: Protein kinase $C \alpha / \beta$ inhibitor Go6976 promotes formation of cell junctions and inhibits invation of urinary bladder carcinoma cells. Cancer Res 2004, 64:5693-570I.

26. Roychowdhury D, Lahn M: Antisense therapy directed to protein kinase C-alpha (Affinitak, LY900003/ISIS 352I): potential role in breast cancer. Semin Oncol 2003, 30:30-33.

27. Rao JS: Molecular mechanisms of glioma invasiveness: the role of proteases. Nat Rev Cancer 2003, 3:489-50 I.

28. Sounni NE, Noel A: Membrane type-matrix metalloproteinases and tumor progression. Biochimie 2005, 87:329-342.

29. Uhm JH, Dooley NP, Villemure J-G, Yong VW: Glioma invasion in vitro: regulation by matrix metalloprotease- 2 and protein kinase C. Clin Exp Metastasis 1996, 14:421-433.

30. Park M-J, Park I-C, Hur J-H, Rhee C-H, Choe T-B, Yi D-H, Hong S-I, Lee $\mathrm{S}-\mathrm{H}$ : Protein kinase $\mathbf{C}$ activation by phorbol ester increases in vitro invasion through regulation of matrix metalloproteinases/tissue inhibitors of metalloproteinases system in D54 human glioblastoma cells. Neuroscience Lett 2000 , 290(3):20I-204.

31. Schiller LR: Review article: anti-diarrhoeal pharmacology and therapeutics. Aliment Pharmacol Ther 1995, 9:87-106.

32. Hwang JM, Kuo HC, Tseng TH, Liu JY, Chu CY: Berberine induces apoptosis through a mitochondria/caspases pathway in human hepatoma cells. Arch Toxicol 2006, 80:62-73.

33. Anis KV, Rajeshkumar NV, Kuttan R: Inhibition of chemical carcinogenesis by berberine in rats and mice. J Pharmacy Pharmacol 200I, 53(5):763-768

34. Kuo CL, Chi CW, Liu TY: The anti-inflammatory potential of berberine in vitro and in vivo. Cancer Lett 2004, 203:I27-I37.

35. Yount G, Qian Y, Moore D, Basila D, West J, Aldape K, Arvold N, Shalev N, Haas-Kogan D: Berberine sensitizes human glioma cells, but not normal glial cells, to ionizing radiation in vitro. J Exp Therapeutics Oncol 2004, 4: I37-143.

36. Peng PL, Hsieh YS, Wang CJ, Hsu JL, Chou FP: Inhibitory effect of berberine on the invasion of human lung cancer cells via decreased productions of urokinase-plasminogen activator and matrix metalloproteinase-2. Toxicol Appl Pharmacol 2006, 2| 4:8-I5.

37. Letašiová S, Jantová S, Čipák L, Mučková M: Berberine-antiproliferative activity in vitro and induction of apoptosis/necrosis of the U937 and B I6 cells. Cancer Lett 2006, 239:254-262.

38. Mantena SK, Sharma SD, Katiyar SK: Berberine inhibits growth, induces $\mathbf{~ I ~}$ arrest and apoptosis in human epidermoid carcinoma A43 I cells by regulating Cdki-Cdk-cyclin cascade, disruption of mitochondrial membrane potential and cleavage of caspase 3 and PARP. Carcinogenesis 2006, 27:2018-2027.

39. Jing $Y$, Dai J, Chalmers-Redman RM, Tatton WG, Waxman S: Arsenic trioxide selectively induces acute promyelocytic leukemia cell apoptosis via a hydrogen peroxide-dependent pathway. Blood 1999, 94:2102-2III.

40. Benda P, Lightbody J, Sato G, Levine L, Sweet W: Differentiated rat glial cell strain in culture. Science 1968, 161:370-37|.

41. Mosmann T: Rapid colorimetric assay for cellular growth and survival: application to proliferation and cytotoxicity assays. J Immunol Methods 1983, 65:55-63.

42. Kuo HC, Kuo WH, Lee YJ, Lin WL, Chou FP, Tseng TH: Inhibitory effect of caffeic acid phenethyl ester on the growth of $\mathrm{C} 6 \mathrm{gli}$ oma cells in vitro and in vivo. Cancer Lett 2006, 234:199-208.

43. Kuo HC, Lee HJ, Hu CC, Shun HI, Tseng TH: Enhancement of esculetin on Taxol-induced apoptosis in human hepatoma HepG2 cells. Toxicol Appl Pharmacol 2006, 21 0:55-62.

44. Pervaiz S: Anti-cancer drugs of today and tomorrow: are we close to making the turn from treating to curing cancer? Curr Pharm Des 2002, 8: $1723-1734$.

45. Larsson C: Protein kinase $\mathbf{C}$ and the regulation of the actin cytoskeleton. Cell Signal 2006, 18:276-284.

46. Sharif TR, Sharif M: Overexpression of protein kinase $C$ epsilon in astroglial brain tumor derived cell lines and primary tumor samples. Int J Oncol I999, I 5:237-243. 
47. Assert R, Kotter R, Bisping G, Scheppach W, Stahlnecker E, Muller KM, Dusel G, Schatz H, Pfeiffer A: Anti-proliferative activity of protein kinase $C$ in apical compartments of human colonic crypts: evidence for a less activated protein kinase $\mathbf{C}$ in small adenomas. Int J Cancer 1999, 80:47-53.

48. da Rocha AB, Mans DR, Regner A, Schwartsmann G: Targeting protein kinase C: new therapeutic opportunities against highgrade malignant gliomas? Oncologist 2002, 7:17-33.

49. Seger R, Krebs EG: The MAPK signaling cascade. FASEB J 1995 , 9:726-735.

50. Schonwasser DC, Marais RM, Marshall CJ, Parker PJ: Activation of the mitogen-activated protein kinase/extracellular signalregulated kinase pathway by conventional, novel, and atypical protein kinase C isotypes. Mol Cell Biol 1998, 18:790-798.

5I. Auvinen M: Cell transformation, invasion, and angiogenesis: a regulatory role for ornithine decarboxylase and polyamines? I Natl Cancer Inst 1997, 89:533-537.

52. Lau CW, Yao XQ, Chen ZY, Ko WH, Huang Y: Cardiovascular actions of berberine. Cardiovasc Drug Rev 200I, 19:234-244.

53. Hwang JM, Wang C], Chou FP, Tseng TH, Hsieh YS, Lin WL, Chu CY: Inhibitory effect of berberine on tert-butyl hydroperoxideinduced oxidative damage. Arch Toxicol 2002, 76:664-670.

54. Bode AM, Dong Z: Apoptosis induction by arsenic: mechanisms of action and possible clinical applications for treating therapy-resistant cancers. Drug Resist Update 2000, 3(I):2 I-29.

55. Cai X, Shen YL, Zhu Q, Jia PM, Yu Y, Zhou L, Huang Y, Zhang JW, Xiong SM, Chen SJ, Wang ZY, Chen Z, Chen GQ: Arsenic trioxideinduced apoptosis and differentiation are associated respectively with mitochondrial transmembrane potential collapse and retinoic acid signaling pathways in acute promyelocytic leukemia. Leukemia 2000, 14:262-270.

56. Levicar N, Nuttall RK, Lah TT: Proteases in brain tumour progression. Acta Neurochir (Wien) 2003, 145:825-838.

57. Bredel M, Pollack IF: The role of protein kinase $\mathbf{C}$ (PKC) in the evolution and proliferation of malignant gliomas, and the application of PKC inhibition as a novel approach to anti-glioma therapy. Acta Neurochir (Wien) 1997, 139:1000-1013.

58. Mandil R, Ashkenazi E, Blass M, Kronfeld I, Kazimirsky G, Rosenthal G, Umansky F, Lorenzo PS, Blumberg PM, Brodie C: Protein kinase Calpha and protein kinase Cdelta play opposite roles in the proliferation and apoptosis of glioma cells. Cancer Res 200I, 61:4612-4619.

59. Dong Z: The molecular mechanisms of arsenic-induced cell transformation and apoptosis. Environ Health Perspect 2002, I 1 0:757-759.

60. Chen NY, Ma WY, Huang C, Ding M, Dong Z: Activation of PKC is required for arsenite-induced signal transduction. J Environ Pathol Toxicol Oncol 2000, 19:297-305.

6I. Au WY, Tam S, Fong BM, Kwong YL: Elemental arsenic entered the cerebrospinal fluid during oral arsenic trioxide treatment of meningeal relapse of acute promyelocytic leukemia. Blood 2006, 107:3012-3013.

\section{Pre-publication history}

The pre-publication history for this paper can be accessed here:

http://www.biomedcentral.com/1471-2407/8/58/prepub

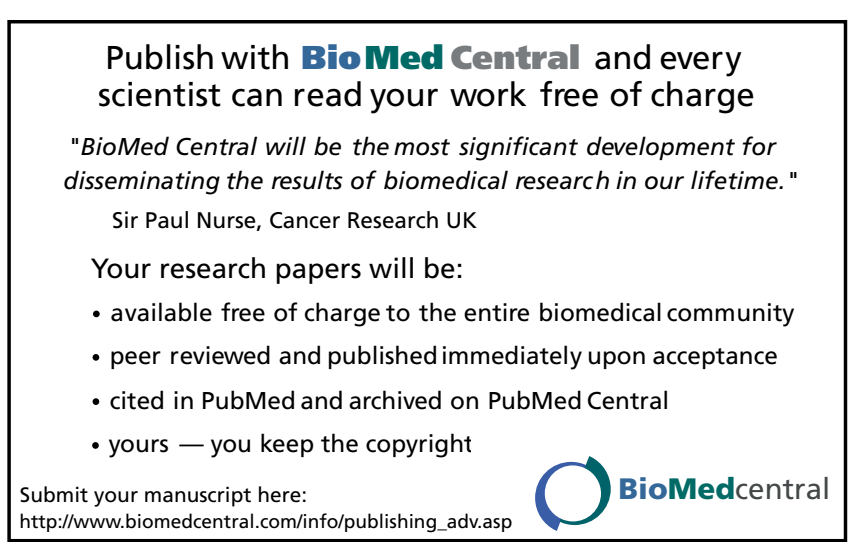

